\title{
THE DOMINANTS OF THE MORAL AND ETHICAL ORIENTATION OF THE PROFESSIONAL TRAINING OF FUTURE PRIMARY SCHOOL TEACHERS
}

\section{ДОМІНАНТИ МОРАЛЬНО-ЕТИЧНОЇ СПРЯМОВАНОСТІ ПРОФЕСІЙНОЇ ПІДГОТОВКИ МАЙБУТНІХ УЧИТЕЛІВ ПОЧАТКОВОї ШКОЛИ}

UDK 378.12:17.02

DOI https://doi.org/10.32843/2663-60852019-17-1-32

Sushchenko L.O.,

Doctor of Pedagogical Sciences,

Professor of the Department

of Social Pedagogy,

Zaporizhzhia National University

Zubtsova Yu.E.,

Candidate of Pedagogical Sciences,

Associate Professor of the Department

of Social Pedagogy,

Zaporizhzhia National University
The article is devoted to the clarification of the essential features of the moral and ethical orientation of the professional training of future primary school teachers in higher education institutions. It is determined that integration processes in the European educational space have activated radical changes of innovative character with realization of certain intermediate goals: support of life-long learning; diversification of educational services; formation and support through teaching, learning and research; actualization of the problem of human-centrism; implementation of competence approach in education; ensuring quality education; expansion of international cooperation programmes, etc.

It has been established that the focus of school education on the final pedagogical result is the formation of pupils' key competences necessary for their successful self-realization in the society include a high level of professional competence of the teachers themselves. Among the key competences that a future primary school teacher should master, moral and ethical competence is a priority.

Dominants of the studied process are scientifically based: profound awareness of future teachers of personal and moral responsibility for the results of their work; cultivating their valuable attitude towards a child; humanization of the educational process in the professional training of future primary school teachers; realization of self-activity principle of the personality of the future specialist as a factor of formation of his/ her professional competence; the orientation of future primary school teachers to moral and ethical self-improvement on a reflexive basis; formation of professional and ethical competence of higher education applicants through the prism of spiritual and moral paradigm.

The priorities of the development of professional education on the basis of ethical pedagogy are characterized, as well as the necessity of its transformation is highlighted.

Key words: dominant, moral and ethical orientation, professional training, future teachers, higher education institution.

Статтю присвячено висвітленню сутнісних особливостей морально-етичної спрямованості профресійної підготовки майбут - ніх учителів початкової школи в закладах вищої освіти.

Визначено, що інтеграційні процеси в європейському освітньому просторі активізували радикальні зміни інноваційного характеру з реалізацією певних проміжних цілей, таких як: підтримка вчення протягом життя; диверсифрікація освітніх послуг формування та підтримка шляхом викладання, навчання і досліджень; актуалізація проблеми гуманоцентризму; реалізація компетентнісного підходу в освіті; забезпечення якості освіти; розширення програм міжнародного співробітництва та ін.

Встановлено, що спрямованість шкільної освіти на кінцевий педагогічний результат - сформованість в учнів ключових компетентностей, необхідних для їхньої успішної самореалізації в суспільстві, передбачає високий рівень профресійної компетентності самих педагогів. Серед ключових компетентностей, якими повинен опанувати майбутній учитель початкової школи, морально-етична має пріоритетне значення.

Науково обгрунтовано домінанти досліджуваного процесу: глибоке усвідомлення майбутніми педагогами особистісно-моральної відповідальності за результати своєї праці; виховання в них ціннісного ставлення до дитини; гуманізація освітнього процесу в просресійній підготовиі майбутніх учителів початкової школи; реалізація принципу самоактивності особистості майбутнього фохівия як фрактора фрормування його профресійної компетентності; орієнтованість майбутніх учителів початкової школи на морально-етичне самовдосконалення на рефрлексивній основі; формування професійно-етичної компетентності здобувачів вищої освіти крізь призму духовно-моральної парадигми.

Охарактеризовано пріоритетні завдання розвитку професійної освіти на засадах етичної педагогіки, а також акцентовано на необхідності ї̈ трансорормації.

Ключові слова: домінанти, моральноетична спрямованість, профресійна підготовка, майбутні педагоги, вищий навчальний заклад.
The problem statement in general terms. The structural and paradigmatic reform of professional pedagogical education in Ukraine necessitated its alignment with the European and world norms. Thus, the integration processes in the European educational space have activated radical changes of innovative character with realization of certain intermediate goals: support of life-long learning; diversification of educational services; formation and support through teaching, learning and research; actualization of the problem of human-centrism; implementation of competence approach in education; ensuring quality education; expansion of international cooperation programmes, etc.

Here is a list of documents in what the main Bologna tools are enshrined:

1) The European Qualifications Framework for Lifelong Learning - EQF/LLL, established within the framework of the Copenhagen Process on the basis of large-scale research and an overview 
of practices in EU countries as complementary to the EQF / EHEA;

2) The Overarching Framework for Qualifications in the European Higher Education Area - EQF/EHEA, based on Dublin descriptors;

3) Steps to develop a national qualifications framework, presented and approved at the London Conference of Ministers responsible for higher education;

- Standards and Guidelines for Quality Assurance in the European Higher Education Area - ESG;

4) European Association for Quality Assurance in Higher Education (ENQA);

5) The Charter of European Universities for Lifelong Learning, etc.

The above sources do not exhaust the list of systematically important materials that reflect the philosophy and essence of Bologna transformations. However, the boundaries of the article do not allow them to be fully reviewed.

Pedagogical universities, positioning themselves as developing institutions with a view to meet European international standards, should conduct a high level of teaching, methodical and research work, ensuring the proper quality of these processes.

But until, without any certain answers and a scientific basis, the questions remain: "How should the modern teacher's training be changed? What are the priorities for professional training of pedagogical staff of the future?".

Only taking into account all trends, and better anticipating their impact on future events, we will be able to provide effective educational activities that will result in a well-trained, competitive young educator of an innovative type of culture, with a holistic, innovative thinking, who is ready to immediately apply knowledge to practice, capable of self-realization and development of a reflexive position under the influence of rapidly changing conditions.

This is a difficult task that requires, above all, the need to relate theory to practice, knowledge to wisdom.

The focus of school education on the ultimate pedagogical result - the formation of pupils' competences necessary for their successful self-realization in society imply a high level of professional competence of modern educators. Among the key competences that a future teacher must master, moral and ethical one is a priority.

Analysis of recent research and publications. There were made a significant contribution to solving the problem of professional training of future teachers by O. Abdullin, A. Aleksyuk, V. Andrushchenko, Y. Babansky, A. Boyko, S. Goncharenko, N. Guziy, N. Demyanenko, I. Ziazyun, N. Kuzmina, V. Lozova, V. Lugoviy, O. Moroz, N. Nichkalo, I. Podlasiy, O. Pekhota, O. Savchenko, V. Semichenko, V. Slastionin, L. Khomich, M. Iarmachenko and others.
Particularly an important contribution in the context of the theory of competence approach have been made by scientists V. Baidenko, V. Bezrukov, V. Bondar, I. Zimnya, I. Ziazun, O. Kovalenko, N. Ostapchuk, A. Khutorsky, V. Yarovy and others.

Certain aspects of professionally-ethical competence were studied by $\mathrm{V}$. Hrytsiv, O. Dubaseniuk, I. Zhadlenko, V. Nagaev, V. Omelyanenko, N. Petrenko, O. Slobodyanyuk, and N. Shevchuk.

Encountering of previously unresolved parts of the common problem referred to the article. The analysis of a wide range of sources and scientific papers on this issue shows that a number of important questions concerning the peculiarities of the moral and ethical component of the professional training of future teachers remain little understood.

The purpose of the article. The purpose of the article is to identify and substantiate the dominant moral and ethical orientation of future primary school teachers in higher education institutions (HEIs).

Outline of the main material of the article. Scientists in the fields of pedagogy, psychology, philosophy, and cultural studies emphasize the training of educators of a qualitatively new generation as carriers of the image of goodness and justice, who are able to confront the immorality of situations, with stable moral and ethical principles and norms, new values of humanistic orientation.

It becomes evident that the moral and ethical component of the professional training of future primary school teachers is of the highest importance, because it is ethics which is a systematic component in its structure, a meta-characteristic of their professional activity.

In our attempts to reach scientific truth, we have assumed that one of the dominant features of the studied process should be a deep awareness of the future personal and moral responsibility of primary school teachers for the results of their work.

The process of forming a morally responsible personality of a future teacher, who would be the subject of his/her own professional and ethical activity, looks quite promising in an appropriate humane developing environment, which creates the conditions for a morally determined content of learning.

A thorough analysis of the psycho-pedagogical literature has offered an opportunity to reveal that the responsibility of each person for his/her actions and acts towards others is his/her basic quality.

It may be safely affirmed that teacher's responsibility is a unique phenomenon; leading moral and will-strong trait; it is the responsibility not only of a particular case, but also of his/her opinion, its content and consequences. It is referred to responsible behaviour, responsible attitude towards oneself, after all, self-responsibility. Such a psychological nature of responsibility allows speaking of the whole spiritual personality of the teacher, which is characterized 
by taking care of the pupil's life, of his happiness, of everyday thinking. In other words, responsibility is a common indicator of humanity, goodwill, open-mindedness, justice, optimism and more.

Therefore, a deep awareness of the future teacher's personal and moral responsibility for the results of his or her work is the ultimate formation; the active development of his consciousness, moreover, the conscious movement of consciousness is directly connected with honesty, responsibility, perseverance, active life position and self-organization.

Recognizing the need for the research in the author's conceptual positions of the category "values", let us consider in detail the aspect of upbringing of the value attitude to the child as the highest pedagogical value by higher education applicants in the specialty 013 Primary Education.

Mastering values, the teacher, including the future teacher, learns, develops and improves his pedagogical activity, becomes a master of his job. In addition, his attitude to the surrounding reality in general and values in particular are formed.

We consider this value attitude as a component of the value-meaning sphere of the individual, which positively reflects the value system of a particular object and determines the purposeful activity of the individual in the cognition of that object, establishing continuous, self-determined, stable relationships with it throughout life. This position was the basis for the substantiation of the phenomenon "the value attitude of future teachers to the child".

In the pedagogy of education of value attitude to the person is solved through the prism of humanization of the educational environment, the recognition of the pupil of the highest value, the respect for his/ her choice, the creation of complete and comfortable conditions for self-disclosure.

The interest and visibility of this approach will be determined by the design of the training system of the specialist with moral and ethical focus, so that its quality is grounded in the focus to the development of one's own hierarchy of values, enhancing the culture of relations, understanding the moral content of others, based on the principles of altruism and tolerance.

Summarizing, the future primary school teacher with a developed value system is an effective carrier of moral and ethical norms and principles, cultured, responsible, caring, sincere, prudent, respectable, who enjoys success together with the child and directs the learning process to a pupil as an equal partner.

Hence, the third dominant is the humanization of the educational process in the professional training of future primary school teachers.

Its essence is manifested in providing opportunities to change the content of professional training on the basis of transcendental pedagogy, pedagogy of higher human values. In addition, only a teacher of high humanistic orientation, spiritually mature personality is able to manage carefully the principles of humanism as fundamental human values.

Its essence is manifested in providing opportunities to change the content of professional training on the basis of transcendental pedagogy, pedagogy of higher human values. In addition, only a teacher of high humanistic orientation, spiritually mature personality is able to manage carefully the principles of humanism as fundamental human values.

This is about structuring the educational process in HEIs on the basis of "equality", "justice" and "humanity", taking into account the principle of individualization; the facilitative support in an ethically oriented pedagogical process aimed at creating a sensual basis for contact, an atmosphere of openness and trust; building the optimal subject-subject interaction of the participants of the educational process that develop humanistic thinking, updating the process of acquiring the necessary perception about the technique of transferring humanistic feelings in communication.

The next dominant of the moral and ethical focus of professional training of students in the HEls, we determine the implementation of the self-activity principle of the personality of the future primary school teacher as a factor in the formation of his/her professional competence.

There is undoubtedly that self-activity is indivisibly linked to personal sense, which is revealed through correlation with the realities of one's life, importance of phenomena and objects, of different values. Thanks to such self-identification, the person becomes aware of personal significance, the importance of certain events. Thus, we see a close interdependence between the level of future teacher's self-activity in mastering social values and the content of the latter which is relevant to its actual needs.

The next logical step in setting up the author's vision of the concept should be the focus of future primary school teachers to moral and ethical self-improvement on a reflective basis.

The main feature of the progressive development of the teacher is his orientation to high professional achievements through one's awareness of the need to change oneself, restructuring one's inner world, which, in turn, determines the ability of the specialist to see new horizons of personal and professional growth.

Therefore, we consider the moral and ethical self-improvement of future primary school teachers as an internal process of qualitative self-change, which occurs at the expense of the teacher's awareness of the need for ethical self-development, competent self-examination, his own reflections and comparisons of his pedagogical activity with other pedagogues who are recognized as an example; motivated, goal-oriented and well-organized spiritual self-movement to the best in himself. 
Let attempt to complement the existing conceptual approaches with another dominant element - the formation of professional and ethical competence of future teachers through the prism of the spiritual and moral paradigm.

The successful realization of this task is of great importance for future primary school teachers with deep theoretical knowledge, practical skills, profound erudition in the scientific field, experience, personal and professional qualities and a system of values that will ensure the effectiveness and efficiency of pedagogical activity.

The future teacher should know how to reach the peak of successful development of pedagogical skill and perfection, to come as close as possible to fully reflect in the pedagogical process of his essential spiritual nature.

It should be emphasized that the value-based vector of the competence approach is a competence-oriented education aimed at not only multifunctional knowledge acquisition by future teachers, acquiring significant competences, but also to ensure an organic combination of moral and ethical culture and intelligence of each individual.

Noting that the focus of professional education in the field of intellectual and moral pedagogy determines the fundamental need to rethink all the factors influencing the researchable process, there is a need to consider in the article the specificities of another dominant - ascending of the personality of a future primary school teacher to high spiritual values.

The point is that during spiritual development of the individual, there is a tendency for inner reflection, there is a sense of identity and others as values, the desire for spiritual self-change, finally, and there is a transition from the previous personal state to the future one - a state of spiritual perfection.

In this regard, there is a need to create a humane development environment, in which the main reference point should be the personality of the student - as the highest pedagogical value; respect for him, his views, beliefs and decisions; enriching the spiritual field of the future specialist; ensuring subject-subject interaction on the basis of moral pedagogy; in the end, the intensification of the educational process (moral and ethical enhancing of the educational content; strengthening and optimization of the cultural orientation of the educational process).

Conclusions. Summarizing, in the article, we have identified and scientifically substantiated the relevant dominants of the moral and ethical orientation of the professional training of future primary school teachers in HEls, in particular: deep awareness of their personal and moral responsibility for the results of their work; upbringing of the value attitude to the child as the highest pedagogical value by future teachers; humanization of the educational process in the professional training of future primary school teachers; realization of the self-activity principle of the personality of the future specialist as a factor of the formation of his professional competence; the orientation of future primary school teachers to moral and ethical self-improvement on a reflective basis; formation of professional and ethical competence of higher education applicants through the prism of the spiritual and moral paradigm and the ascension of the personality of the future teacher to the high values of spirituality.

The variant presented in the article does not exhaust all its aspects. Further exploration should be given to the matter of the careers of future primary school teachers and their preparation for facilitating interaction with pupils.

\section{REFERENCES:}

1. Сущенко Л.О. Безперервна освіта: особистісний і професійний онтогенез. Педагогічний дискурс : зб. наук. праць / гол. ред. І.М. Шоробура. Хмельницький, 2016. Вип. 21. С. 155-159.

2. Хоружа Л.Л. Етичний розвиток педагога : навч. посіб. Київ : Академвидав, 2012. 208 с. 